\title{
Assessment of radiological risk in the area around surface disposal at
}

\section{Al - Tuwaitha site}

\author{
Saad M. Abd ${ }^{1}$, Taha Yaseen Mansoor ${ }^{1}$, Muna A. Saaeed ${ }^{2}$, Asia H. \\ Al-Mashhadani ${ }^{2}$ \\ ${ }^{1}$ Ministry of Science and Technology \\ ${ }^{2}$ Department of Physics, College of Science, University of Baghdad \\ E-mail: assia19662006@yahoo.com
}

\begin{abstract}
The gamma dose rates and specific activity of ${ }^{137} \mathrm{Cs},{ }^{60} \mathrm{Co}$ and ${ }^{40} \mathrm{~K}$ in samples of soil taken from places near the landfill radiation at AlTuwaitha site were measured using a portable $\mathrm{NaI}(\mathrm{Tl})$ detector. The results of gamma dose rates in samples were ranged from 52.6 nGy. $\mathrm{h}^{-1}$ to $131 \mathrm{nGy} \cdot \mathrm{h}^{-1}$. Then the specific activity of ${ }^{137} \mathrm{Cs},{ }^{60} \mathrm{Co}$ and ${ }^{40} \mathrm{~K}$ in soil were determined using high pure germanium (HPGe) detector. The specific activities were varied from 1.9 to $115500 \mathrm{~Bq}$. $\mathrm{kg}^{-1}$ for ${ }^{137} \mathrm{Cs}$, from 6.37 to $616.5 \mathrm{~Bq} . \mathrm{kg}^{-1}$ for ${ }^{60} \mathrm{Co}$, and from 3 to $839.5 \mathrm{~Bq} . \mathrm{kg}^{-1}$ for ${ }^{40} \mathrm{~K}$. The corresponding health risk for the annual effective dose equivalent varied from $1.85 \times 10^{-14}$ to $15.7 \mathrm{mSv} / \mathrm{y}$. The results were compared with various international recommendations.
\end{abstract}

Key words

${ }^{137} \mathrm{Cs},{ }^{60} \mathrm{Co}$ and ${ }^{40} \mathrm{~K}$, Annual Effective

Dose Equivalent.

\section{Article info.}

Received: Feb. 2016

Accepted: Mar. 2016

Published: Sep. 2016

$$
\begin{aligned}
& \text { تقييم المخاطر الإشعاعية في المنطقة المحيطة بسطح مخازن الطمر الاشعاعي في موقع آلتويثة } \\
& \text { سعد محمد عبد1، طه ياسين منصور 1، منى احمد سعيد²، اسيا حميد المشهداني2 }
\end{aligned}
$$

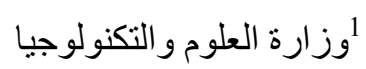

$$
\begin{aligned}
& \text { 2قسم الفيزياء، كلية العلوم، جامعة بغداد }
\end{aligned}
$$

الخلاصة

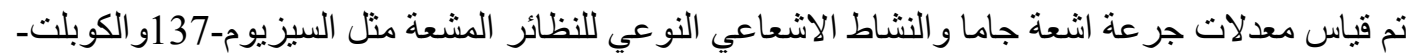

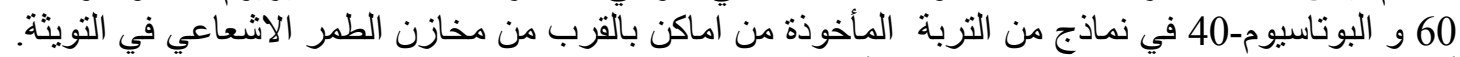

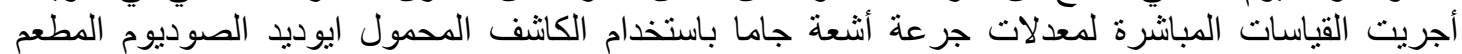

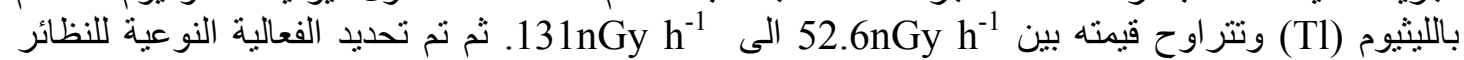

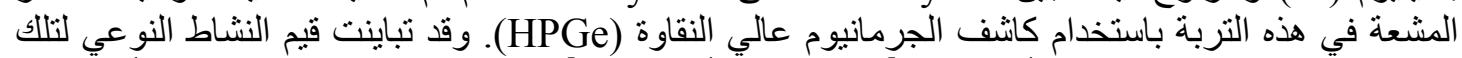

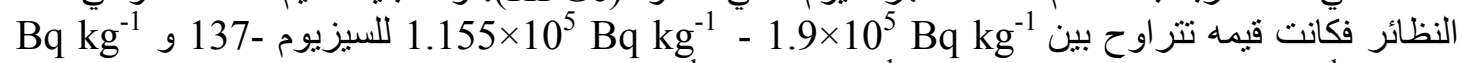

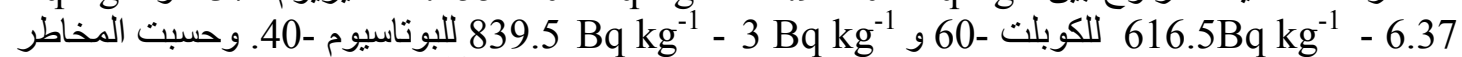
الصحية المقابلة للجرعة السنوية الفعالة وكانت قيمها تتراوح من وتمت مقارنة النتائج مع مختلف التوصيات الدوعة الدولية.

\section{Introduction}

The Russian cemetery (RC) which was built in the early sixties of the last century at Al-Tuwaitha site, it called Russian Silo too, is a building similar the silo, it was designed for store low radioactive waste. Radioactivity is part of everyday life. Depending on the typology of the source it is possible to divide it in natural and artificial radioactivity. Artificial radioactivity derives from man activity and is generated in different applications, ranging from nuclear installations, nuclear accident or normal radionuclides applications used in 
industry, e.g. medical machinery and different kinds of electronic devices. The primary man-made products are ${ }^{90} \mathrm{Sr}$ and ${ }^{137} \mathrm{Cs}[1]$.

Soil contamination is caused by the presence of man-made chemicals or other alteration in the natural soil environment. There are many different ways that soil can become polluted, such as:

- Leakage from a landfill

- Inflection of industrial waste into the soil

- Percolation of contaminated water into the soil

- Rupture of underground storage tanks

- Excess application of pesticides, herbicides or fertilizer

- Solid waste seepage

Estimation of the external exposure due to gamma-ray radiation is important because this may contribute significantly to the total annual individual dose [2]. The term for the absorption of radiation by living organisms is dose. The United States uses the Roentgen Equivalent Man (rem) as the unit of equivalent dose in humans. Rem relates the absorbed dose in human tissue to the effective biological damage of the radiation. Not all radiation has the same biological effect, even for the same amount of absorbed dose, as some forms of radiation are more efficient than others in transferring their energy to living cells [3]. The absorbed dose refers to how much energy is deposited in material by the radiation [4].

Radiological impacts may arise from gradual processes which may cause the facility and its components (e.g. barriers) to degrade, and from discrete events that may affect the isolation of the waste (e.g. earthquakes, tsunamis, floods, fire, inadvertent human intrusion) [5].

There are no studies that identify the leaks that contaminated or discharge of industrial waste from the
Russian cemetery to soil surrounding areas. Therefore, this research aims to a considerable amount of detail regarding the contaminated soil, sample data so the determine basis for the estimates of the amount of waste leaked and its source term.

\section{Materials and methods}

\section{The study area}

The RC was used for disposal of low radioactivity and contains around 100 concrete wells of $4 \mathrm{~m}$ depth, which means the cemetery was built on top of $1 \mathrm{~m}$ concrete slab. There are three sections in RC: Square wells, cylindrical wells and two large stainless steels.

The dimensions of the building from the outside are $60 \mathrm{~m} \times 10 \mathrm{~m} \times 4 \mathrm{~m}$. This cemetery is located at AlTuwaitha site, a nuclear research center $18 \mathrm{~km}$ south of Baghdad. RC is still intact and contains radioactive waste of the sixties, seventies and eighties.

\section{In situ gamma dose rates measurement}

Ludlum Model 19 Micro R Meter, USA was used to measure the gamma dose rates at 1 meter above the ground of sampling location. The instrument has linear energy responses to gamma radiation between 0.08 and $1.2 \mathrm{MeV}$ [6]. It covered the majority of gamma ray emissions from major sources. The instrument uses scintillator, $2.5 \times 2.5$ $\mathrm{cm}(1 \times 1$ in.) (Dia $\times$ L) thick Nal. The survey meters were calibrated at the Malaysian Nuclear Agency, which is recognised by the IAEA as a Secondary Standards Dosimetry Laboratory. The meter display was in microroentgen per hour $\left(\mu \mathrm{R} \mathrm{h} \mathrm{h}^{-1}\right)$. The gamma dose rate in unit $\mu \mathrm{R} \mathrm{h}^{-1}$ was converted to unit $\mu \mathrm{Gy} \mathrm{h}^{-1}\left(1 \mu \mathrm{R} \mathrm{h}^{-1}=\right.$ $0.00876 \mu \mathrm{Gy} \mathrm{h}^{-1}$ ). 


\subsection{Samples collection and preparation}

A total 13 samples were taken from several locations above and surface surrounding the RC building. The samples were dried in an oven at 120 ${ }^{0} \mathrm{C}$ for 48 hours. The samples were grinded to form powder and then sieved by a sieve of $315 \mu \mathrm{m}$. The samples of $500 \mathrm{~g}$ kept in a cylindrical container. The samples were stored for a month to get equilibrium between $\mathrm{Ra}$ with its daughter.

\subsection{Measurements of specific activity}

The specific activity of ${ }^{137} \mathrm{Cs},{ }^{60} \mathrm{Co}$ and ${ }^{40} \mathrm{~K}$ were measured using spectrometer with a coaxial high purity germanium detector (GC2018-7500 SL). It has a relative efficiency of $40 \%$, and a resolution of $1.8 \mathrm{keV}$ for 1332 $\mathrm{keV}$ gamma ray emission of ${ }^{60} \mathrm{Co}$. Gamma vision version (6.8) software for gamma spectrum analysis a gamma spectrometer and relevant accessories were supplied by Canberra, USA [7].

The calibration was carried out by counting standard radionuclides of known activities with well-defined energies within the energy range of interest from $60 \mathrm{keV}$ to $2000 \mathrm{keV}$ and used standard source for efficiency calibration of gamma ray spectrometer in measuring large volumes of low specific activity materials [8].

The radionuclides were identified according to their individual photopeak radioactive. The activity of ${ }^{137} \mathrm{Cs}$ was directly determined using its 661.6 $\mathrm{keV}, 1173.24 \mathrm{keV}$ for ${ }^{60} \mathrm{Co}$, and 1460.8
$\mathrm{keV}$ of ${ }^{40} \mathrm{~K}$ photopeak. The concentration of each individual radionuclide was calculated by the following equation [9].

$W_{s}=\frac{W_{C R M} \cdot S_{s}}{M_{s} \cdot S_{C R M}} \cdot M_{C R M}$

where $W_{s}$ is the concentration of the radionuclide in the sample $\left(\mathrm{Bq} . \mathrm{kg}^{-1}\right)$, $W_{C R M}$ is the concentration of the radionuclide in the standard $\left(\mathrm{Bq} \cdot \mathrm{kg}^{-1}\right)$, $M_{S}$ is the weight of the sample $(\mathrm{g})$; $M_{C R M}$ is the weight of the standard (g), $S_{S}$ is the counts of the sample (cps) and $S_{C R M}$ is the counts of the standard (cps). An empty cylindrical container of the same volume as the sample was counted to determine the background distribution due to the naturally occurring radionuclides in the environment around the detector area.

\section{Results and discussions 1.External gamma dose rates}

Two methods have been used to evaluate external exposures of gamma dose rate in this study area. The first was direct measurement of external gamma dose rates; the reading was taken at $1 \mathrm{~m}$ above the ground using $\mathrm{NaI}$ gamma detector [10]. The external gamma dose rate ranges from 52.6nGy $\mathrm{h}^{-1}$ to $131 \mathrm{nGy} \cdot \mathrm{h}^{-1}$ as shown in Table 1.

\section{Specific activity of ${ }^{137} \mathrm{Cs},{ }^{60} \mathrm{Co}$ and} ${ }^{40} \mathrm{~K}$.

The specific activity of ${ }^{137} \mathrm{Cs},{ }^{60} \mathrm{Co}$ and ${ }^{40} \mathrm{~K}$ samples were measured using HPGe detector and the results are tabulated in Table 2. 
Table 1: The direct measurements of gamma dose rate for the samples collected from a surface and above the RC (nGy/h).

\begin{tabular}{cccc}
\hline ID & Situ & Dose Rate in $\boldsymbol{\mu R} / \mathbf{h}$ & $\begin{array}{c}\text { Measured gamma dose rate } \\
(\mathbf{n G y} / \mathbf{h})\end{array}$ \\
\hline 1 & & 15 & 131.40 \\
2 & Left side & 12 & 105.12 \\
3 & Back deep 30 cm & 9 & 78.84 \\
4 & Above situ (circular wells) & 8 & 122.64 \\
5 & Next to the situ & 9 & 131.40 \\
6 & Right side & 9 & 78.84 \\
7 & Above situ (square wells) & 7 & 105.12 \\
8 & Above situ (square wells) & 6 & 87.60 \\
9 & Above situ (square wells) & 8 & 96.36 \\
10 & Right side & 9 & 78.84 \\
11 & Right side on deep 30 cm & 8 & 70.08 \\
12 & Lift side & 9 & 131.40 \\
13 & Lift side on deep 30 cm & 6 & 113.88 \\
\hline
\end{tabular}

Table 2: The specific activity of ${ }^{137} \mathrm{Cs},{ }^{60} \mathrm{Co}$ and ${ }^{40} \mathrm{~K}$ in the samples collected from a surface and above the $R C$

\begin{tabular}{ccccc}
\multirow{2}{*}{$\begin{array}{c}\text { Sample } \\
\text { No. }\end{array}$} & Situ & \multicolumn{3}{c}{ Specific activity (Bq.kg ${ }^{-\mathbf{1}}$ ) } \\
\cline { 3 - 5 } & & & & \\
\cline { 3 - 5 } & & ${ }^{\mathbf{1 3 7}} \mathbf{C s}$ & ${ }^{\mathbf{6 0}} \mathbf{C o}$ & ${ }^{40} \mathbf{K}$ \\
\hline 1 & Left side & 96300 & 600.3 & 7.7 \\
2 & Left side deep 30 cm & 59800 & 339.9 & 3 \\
3 & Back situ & 116000 & 616.5 & 10 \\
4 & Above situ (circular wells) & 104.8 & 6.37 & 261 \\
5 & Next to the situ & 23.19 & 14.6 & 326 \\
6 & Right side I & 65.16 & 4.8 & 151.6 \\
7 & Above situ (square wells) I & 389.2 & 11.59 & 137.8 \\
8 & Above situ (square wells) II & 426.4 & 8.3 & 45.5 \\
9 & Above situ (square wells) III & 269.5 & 6.5 & 11.7 \\
10 & Right side II & 26.86 & 6.8 & 839.5 \\
11 & Right side on deep 30 cm & 4438 & 6.8 & 292.6 \\
12 & Back left side & 59.8 & 172.8 & 243.3 \\
13 & Back left side on deep 30 cm & 1.9 & 58 & 7.7
\end{tabular}

The measured specific activity of ${ }^{137} \mathrm{Cs}$ varies from $1.9 \mathrm{~Bq} \cdot \mathrm{kg}^{-1}$ to 116000 Bq. $\mathrm{kg}^{-1}$ as shown in Fig. 1 . The highest specific activity of ${ }^{137} \mathrm{Cs}$ was found in the Back situ sample while left side deep $30 \mathrm{~cm}$ has the lowest activities. 


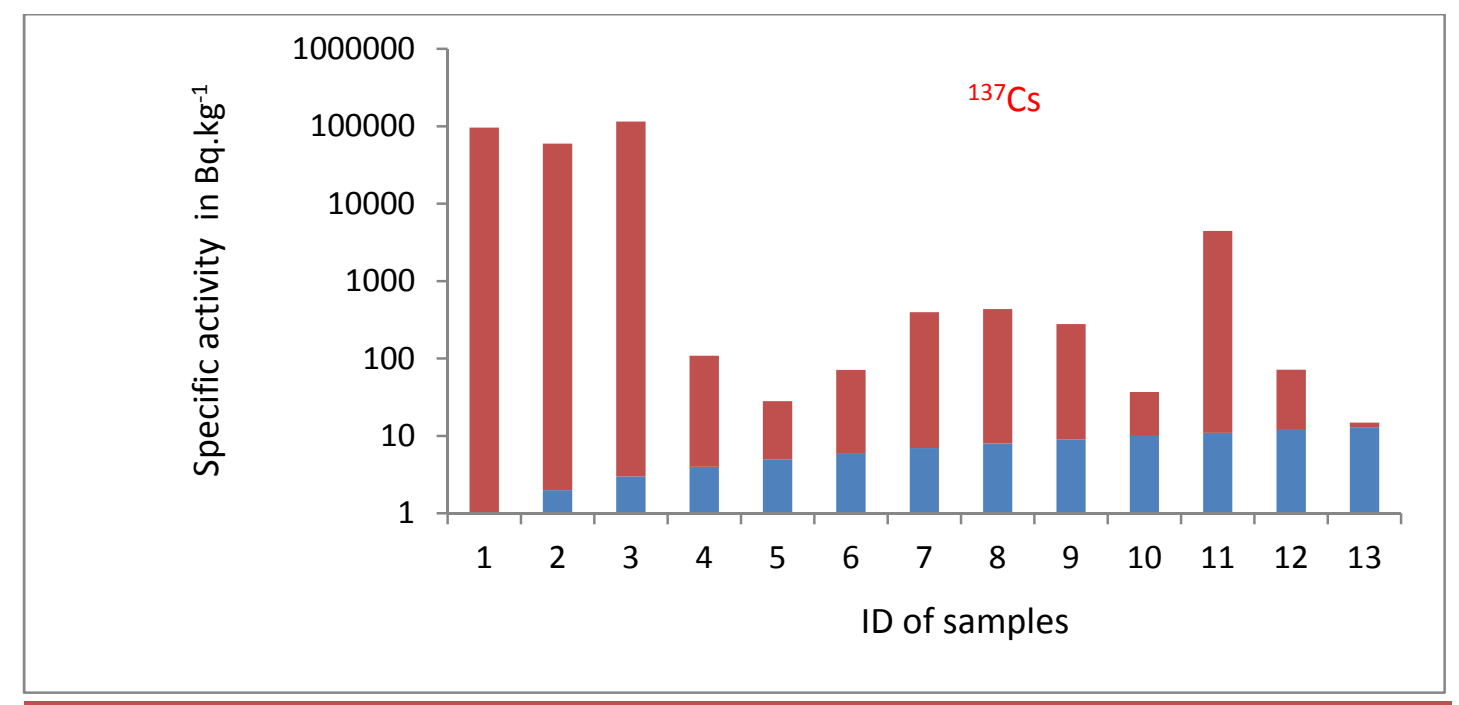

Fig.1: The specific activity of ${ }^{137} \mathrm{Cs}$ in the samples collected from a surface and above the RC.

The specific activity of ${ }^{60} \mathrm{Co}$ varies from $4.8 \mathrm{~Bq} \cdot \mathrm{kg}^{-1}$ to $616.5 \mathrm{~Bq} \cdot \mathrm{kg}^{-1}$ as shown in Fig. 2. The highest specific activity of ${ }^{60} \mathrm{Co}$ was found in the Back situ sample.

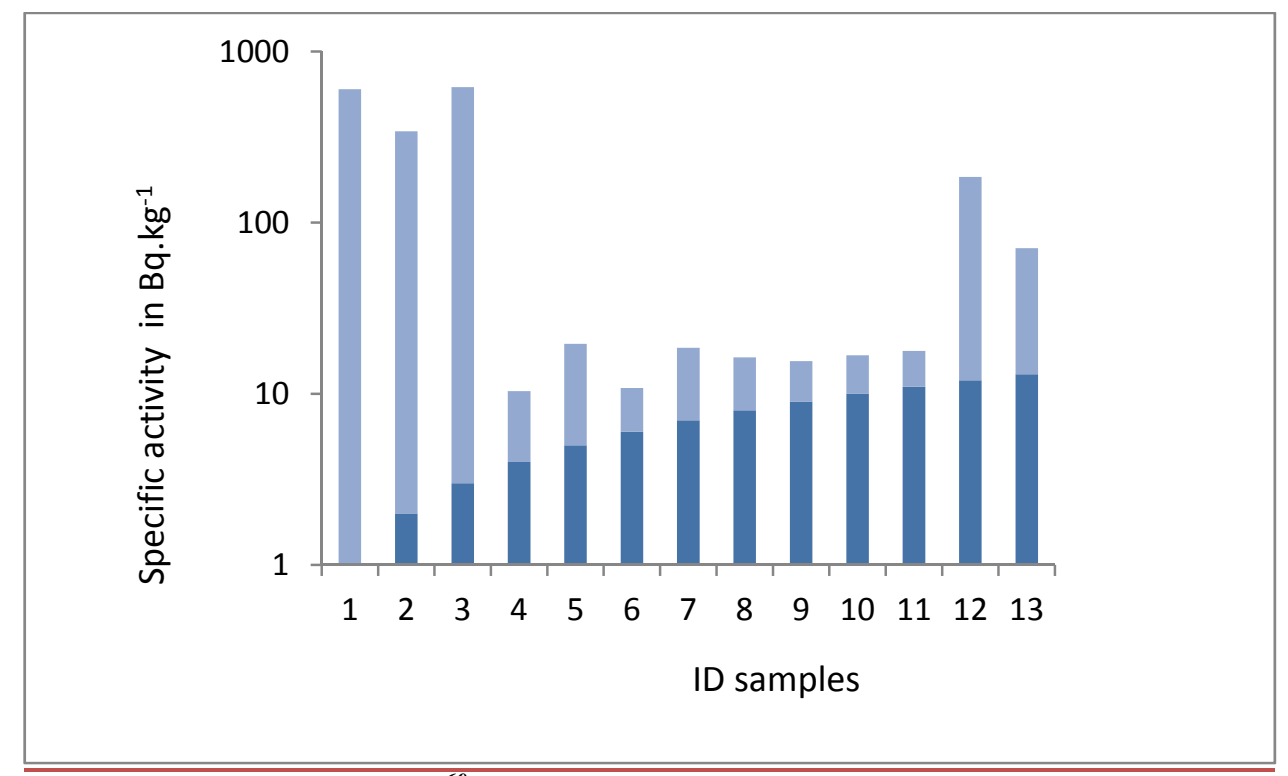

Fig.2: The specific activity of ${ }^{60}$ Co in the samples collected from an among processing plant.

${ }^{40} \mathrm{~K}$ specific activity varies from 3Bq. $\mathrm{kg}^{-1}$ to $839.5 \mathrm{~Bq} \cdot \mathrm{kg}^{-1}$ as shown in Fig. 3. Right side has highest specific activity of ${ }^{40} \mathrm{~K}$ while back left side deep $30 \mathrm{~cm}$ has the lowest activities. 


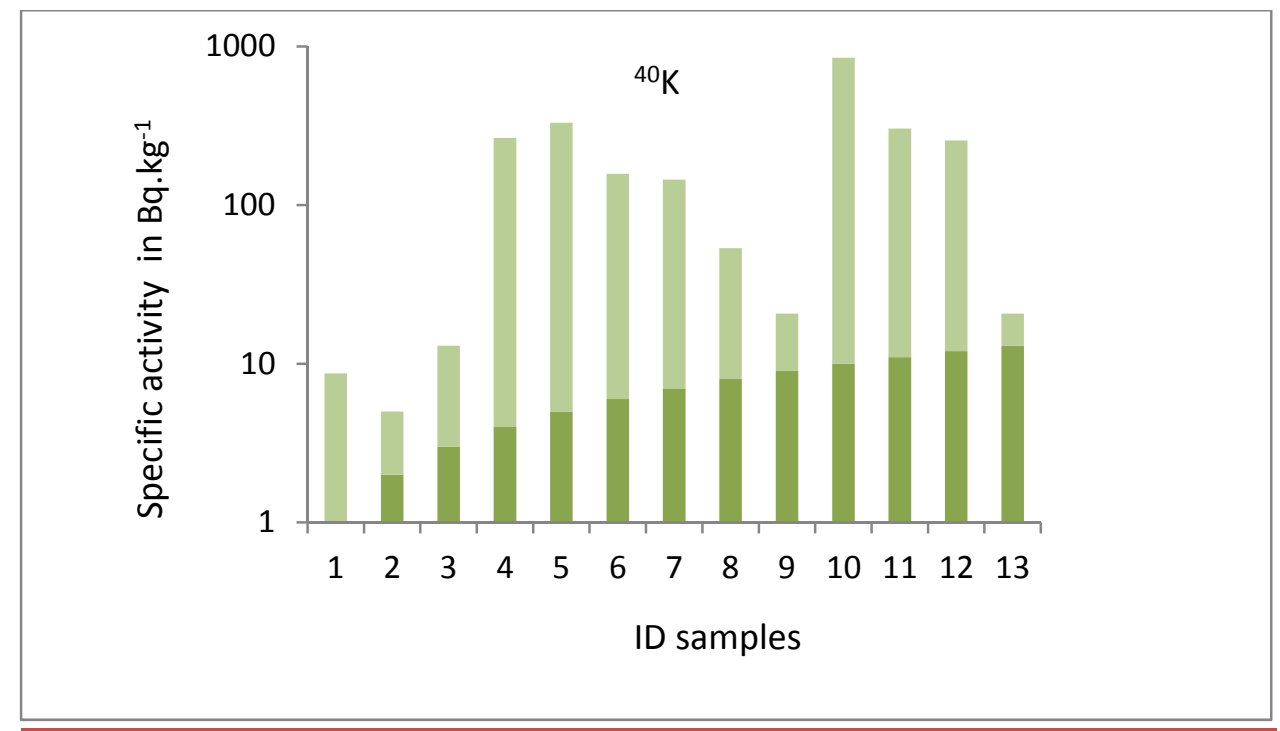

Fig.3: The specific activity of ${ }^{40} \mathrm{~K}$ in the samples collected from a surface and above the $R C$.

Figs. 1, 2 and 3 show that the radioactivity measurements for samples of soil is relatively high for ${ }^{137} \mathrm{Cs}$ and ${ }^{60} \mathrm{Co}$ radionuclides in left and back situ when they compared with other samples while the activity of ${ }^{40} \mathrm{~K}$ was increased in the right side.

The absorbed gamma dose rates of the samples were also calculated based on the specific activity of ${ }^{137} \mathrm{Cs},{ }^{60} \mathrm{Co}$ and ${ }^{40} \mathrm{~K}$ in the collected samples as represented in Table 3. The methodology used for the derivation of the gamma dose rates from the activity of ${ }^{137} \mathrm{Cs}$, ${ }^{60} \mathrm{Co}$ and ${ }^{40} \mathrm{~K}$ was adopted from UNSCEAR (2000) using Eq.(2), [11].

$D_{\text {Medium }}=D_{\text {Air }} \frac{\mu_{m}(\text { Medium })}{\mu_{m}(\text { Air })}$

where $\mathrm{D}_{\text {medium }}$ - Absorbed dose rate in medium.

$\mu_{\mathrm{m}}-$ The mass attenuation coefficient [12].

$\mathrm{D}_{\text {air }}-$ Absorbed dose rate in air.

Table 3: The absorbed dose rate of ${ }^{137} \mathrm{Cs},{ }^{60} \mathrm{Co}$ and ${ }^{40} \mathrm{~K}$ in the samples collected from

ID Absorbed dose $\left({ }^{137} \mathrm{Cs} \mathrm{mGy} / \mathrm{h}\right)$

1
2
3
4
5
6
7
8
9
10
11
12
13

$1.11 \mathrm{E}-02$

$6.28 \mathrm{E}-03$

4.13E-03

3.75E-06

8.31E-07

2.33E-06

$1.39 \mathrm{E}-05$

$1.53 \mathrm{E}-05$

9.65E-06

$9.62 \mathrm{E}-07$

$1.59 \mathrm{E}-04$

$2.14 \mathrm{E}-06$

$6.80 \mathrm{E}-08$ a surface and above the $R C$.

Absorbed dose

$\left({ }^{60} \mathrm{Co} \mathrm{mGy} / \mathrm{h}\right)$

$7.41 \mathrm{E}-05$

$4.20 \mathrm{E}-05$

$7.61 \mathrm{E}-05$

$7.86 \mathrm{E}-07$

$1.80 \mathrm{E}-06$

$5.92 \mathrm{E}-07$

$1.43 \mathrm{E}-06$

$1.02 \mathrm{E}-06$

$8.02 \mathrm{E}-07$

$8.39 \mathrm{E}-07$

8.39E-07

$2.13 \mathrm{E}-05$

7.16E-06

\section{Absorbed dose}

$\left({ }^{40} \mathrm{~K} \mathrm{mGy} / \mathrm{h}\right)$

5.97E-06

$2.32 \mathrm{E}-06$

$7.75 \mathrm{E}-06$

2.02E-04

2.53E-04

$1.17 \mathrm{E}-04$

$1.07 \mathrm{E}-04$

3.53E-05

$9.07 \mathrm{E}-06$

6.51E-04

2.27E-04

$1.89 \mathrm{E}-04$

5.97E-06
Total absorbed dose (nGy/h)

$1.12 \mathrm{E}+04$

$6.32 \mathrm{E}+03$

$4.21 \mathrm{E}+03$

$2.07 \mathrm{E}+02$

$2.56 \mathrm{E}+02$

$1.20 \mathrm{E}+02$

$1.22 \mathrm{E}+02$

$5.16 \mathrm{E}+01$

$1.95 \mathrm{E}+01$

$6.53 \mathrm{E}+02$

$3.87 \mathrm{E}+02$

$2.12 \mathrm{E}+02$

$1.32 \mathrm{E}+01$ 
Fig.4 shows the relation between measured and calculated gamma dose rate in the samples. The correlation coefficient was very good $(0.9185)$ between measured and the calculated gamma dose rates from the radionuclides ${ }^{137} \mathrm{Cs},{ }^{60} \mathrm{Co}$ and ${ }^{40} \mathrm{~K}$. The significant linear relationship between measured and the calculated gamma dose rates indicate that the calculated or measured gamma dose rates could be used to predict the other.

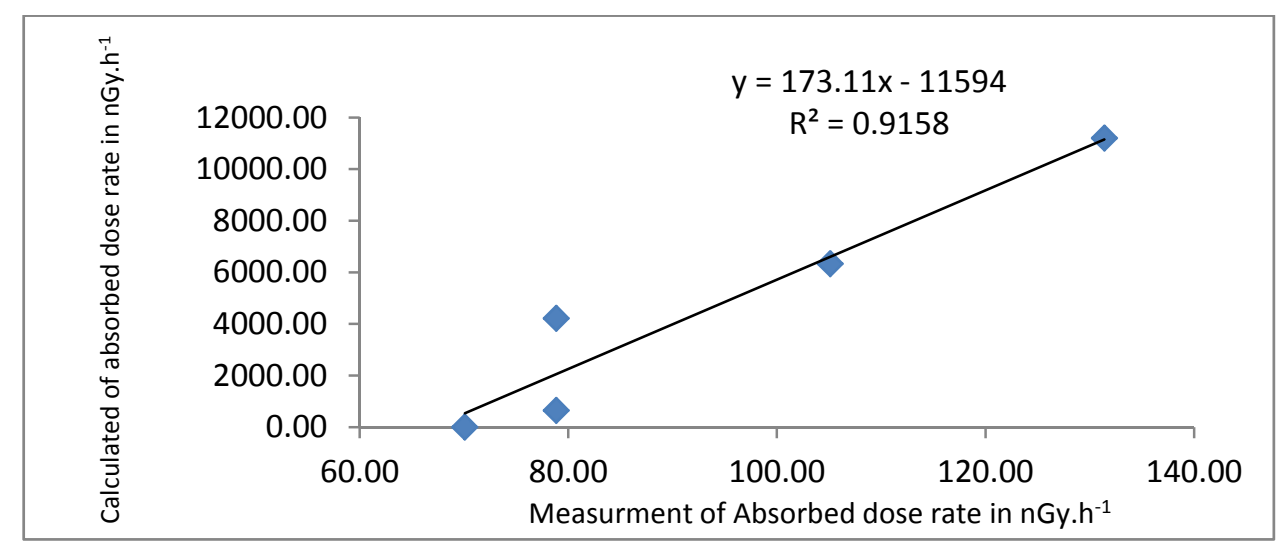

Fig 4: The correlation between measured and calculated absorbed gamma dose rate in the samples.

\section{Annual Effective Dose Equivalent} (AEDE)

Annual effective dose equivalent (AEDE) was used to assess the external radiological health risk worker. In order to estimate the annual effective dose equivalent, the conversion coefficient, $0.7 \mathrm{~Sv} \mathrm{~Gy}^{-1}$ from the absorbed dose in air to effective dose and the average working time at RC of $2000 \mathrm{~h}$ annually were used (ICRP1990). It can be calculated by using Eq. (3) [13].

$$
A E D E\left(m S v y^{-1}\right)=D\left(n G y h^{-1}\right) \times 2000 h \times 0.7\left(S v . G y^{-1}\right) \times 10^{-6}
$$

The annual effective dose equivalent was calculated for the sample of the soil based on the calculated gamma dose rate. The results were in the range from $1.85 \mathrm{E}-14 \mathrm{mSv}$ to $1.57 \mathrm{E}+01 \mathrm{mSv}$ as shown in Table 4. Left side, Left side deep $30 \mathrm{~cm}$ and Back situ could pose significant radiological health risk to among workers since the annual effective dose equivalent is greater than the recommended value by ICRP (1991).

\section{Conclusions}

The external gamma dose rate and specific activity of ${ }^{137} \mathrm{Cs},{ }^{60} \mathrm{Co}$ and ${ }^{40} \mathrm{~K}$ in the samples collected from the site, were measured to assess the radiological health risk to the workers.
The external gamma dose rates were varied from 78.8 to $131 \mathrm{nGy} \mathrm{h}^{-1}$ which the highest gamma dose rate was recorded in Left side, Left side deep 30 $\mathrm{cm}$ and Back situ. The specific activity of radionuclides ${ }^{137} \mathrm{Cs},{ }^{60} \mathrm{Co}$ and ${ }^{40} \mathrm{~K}$ were varied from $1.9 \mathrm{~Bq} \cdot \mathrm{kg}^{-1}$ to $116000 \mathrm{~Bq} \cdot \mathrm{kg}^{-1}$ these values were to have a significant potential to cause elevated radiation exposures to the workers. The mean annual effective dose equivalent was calculated in the range from $1.85 \mathrm{E}-14 \mathrm{mSv}$ to $1.57 \mathrm{E}+01$ $\mathrm{mSv}$. When compared the results with the ICRP recommendations the calculated annual effective dose equivalent of the samples was low and one can notice don't exist risk in the site. 
Table 4: The calculated gamma dose rate from ${ }^{137} \mathrm{Cs},{ }^{60} \mathrm{Co}$ and ${ }^{40} \mathrm{~K}$ and annual effective dose equivalent.

\begin{tabular}{|c|c|c|}
\hline ID & $\begin{array}{l}\text { The calculated gamma dose rate } \\
\left(\mathrm{nGy} \mathrm{h}^{-1}\right)\end{array}$ & $\begin{array}{c}\text { Annual effective dose equivalent } \\
(\mathrm{mSv})\end{array}$ \\
\hline 1 & $1.12 \mathrm{E}+04$ & $1.57 \mathrm{E}+01$ \\
\hline 2 & $6.32 \mathrm{E}+03$ & $8.86 \mathrm{E}+00$ \\
\hline 3 & $4.21 \mathrm{E}+03$ & $5.91 \mathrm{E}+00$ \\
\hline 4 & $2.07 \mathrm{E}+02$ & $2.90 \mathrm{E}-01$ \\
\hline 5 & $2.56 \mathrm{E}+02$ & $3.57 \mathrm{E}-01$ \\
\hline 6 & $1.20 \mathrm{E}+02$ & $1.68 \mathrm{E}-01$ \\
\hline 7 & $1.22 \mathrm{E}+02$ & $1.71 \mathrm{E}-01$ \\
\hline 8 & $5.16 \mathrm{E}+01$ & $7.22 \mathrm{E}-02$ \\
\hline 9 & $1.95 \mathrm{E}+01$ & $2.73 \mathrm{E}-02$ \\
\hline 10 & $6.53 \mathrm{E}+02$ & $9.13 \mathrm{E}-01$ \\
\hline 11 & $3.87 \mathrm{E}+02$ & $5.42 \mathrm{E}-13$ \\
\hline 12 & $2.12 \mathrm{E}+02$ & $2.97 \mathrm{E}-13$ \\
\hline 13 & $1.32 \mathrm{E}+01$ & $1.85 \mathrm{E}-14$ \\
\hline
\end{tabular}

\section{References}

[1] Nicola Pallavicini, Activity concentration and transfer factors of natural and artificial radionuclides in the Swedish counties of Uppsala and Jämtland, M.Sc. Thesis in Environmental Science Environmental Science in Europe - Master's Programme, 2011.

[2] D. Okrent, Risk Analysis 19 (1999) 877-901.

[3] International Commission on Radiological Protection, (ICRP 60) Radioactive Waste Streams: An Overview of Waste Classification for Disposal, Pergamon Press, Oxford 1977.

[4] D. Bodansky, Nuclear Energy, Principles, Practices, and Prospects, Second Edition, Seattle, Washington, May 2004.

[5] International Atomic Energy Agency, Classification of Radioactive Waste, IAEA Safety Series No. 111G1.1, IAEA, Vienna, 1994.

[6] Glenn F. Knoll, Radiation Detection and Measurement, Fourth Edition, Wiley, 2010.

[7] ORTEC $®$ Micro-Detective ${ }^{\circledR}-H X$. Enhanced Capability ultra-light.
Portable Ha-Held Radioisotope Identifier.

[8]. International Atomic Energy Agency (IAEA), "Measurement of Radionuclides in Food and the Environment". Technical Report Series No. 295, Vienna: IAEA Publication, (1989).

[9] A. Mohanty, D. Sengupta, S. Das, S. Saha, K.Van, Journal of Environmental Radioactivity, 75, 1 (2004) 15-33.

[10] Ludlum Model 19 Micro R Meter, serial number 207422 and succeeding serial number, technical manual 2005.

[11] International Commission on Radiological Protection, Annals of the ICRP, Occupational Intakes of Radionuclides, Part 1, 2012 February 23.

[12] Chaudhari, Raje Dayanand, Research Journal of Recent Sciences, 1, 9 September (2012) 41-48.

[13] International Commission on Radiological Protection, recommendations of the International Commission on Radiological Protection, ICRP Publication 103, Pergamon Press, Oxford, 2007. 